\title{
Keterbukaan Perdagangan, Inflasi, Jumlah Tenaga Kerja dan Pertumbuhan Ekonomi di Indonesia
}

\author{
Khoirul Ifa, Neny Tri Indrianasari, Fetri Setyo Liyundira
}

Sekolah Tinggi Ilmu Ekonomi Widya Gama Lumajang

Email: khoirul.ifa@gmail.com_Indriana85@gmail.com_Liyundira90@gmail.com

\begin{tabular}{l}
\hline Article Info \\
\hline Article history: \\
Published: Dec 25,2020 \\
Page: $10-23$ \\
\hline
\end{tabular}

Keyword:

Keterbukaan

Perdagangan, Inflasi,

Tenaga Kerja dan

Pertumbuhan Ekonomi

\section{Abstract}

Penelitian ini merupakan penelitian kuantitatif teknik analisis data menggunakan metode GMM untuk melihat dampak keterbukaan perdagangan terhadap pertumbuhan ekonomi. Hasil pengujian menggunakan metode analisis Generalized Method of Moments menujukkan bahwa seluruh variable berpengaruh signifikan terhadap dinamika pertumbuhan ekonomi di Indonesia. Dapat disimpulkan bahwa pada variabel perdagangan, inflasi, dan jumlah tenaga kerja berpengaruh signifikan terhadap pertumbuhan ekonomi di Indonesia.

Kata Kunci : Keterbukaan Perdagangan, Inflasi, Tenaga Kerja dan Pertumbuhan Ekonomi

This research is a quantitative study using time series data from 1986 to 2018, research data obtained from the world bank, data analysis techniques using the GMM method to see the impact of trade openness on economic growth. The test results using the Generalized Method of Moments analysis method show that all variables have a significant effect on the dynamics of economic growth in Indonesia.. Then this value also has a probability of less than the $\alpha$ value. It can be concluded that the variables of trade, inflation, and the number of workers have a significant effect on economic growth in Indonesia.

\section{Copyright ( 2020 OECONOMICUS Journal of Economics}

\section{Pendahuluan}

Setiap negara memiliki keuntungan dengan adanya keterbukaan perdagangan yaitu memperoleh pembukaan akses pasar yang luas, pencapaian efisiensi dan daya saing ekonomi yang tinggi disetiap negara dan mendapatkan peluang besar penyerapan tenaga kerja. Sementara itu, keterbukaan di sektor finansial dapat mendorong masuknya modal asing (capital inflow), serta mempercepat terjadinya akumulasi modal dan transfer teknologi (Salvatore, 1997).

\section{Editorial Office:}

Prodi Ilmu Ekonomi Fakultas Ekonomi dan Bisnis Islam, UIN Sunan Ampel Surabaya

Jl. Ahmad Yani 117 Surabaya, Jawa Timur 60237, Indonesia.

Email: oje@uinsby.ac.id 
Pertumbuhan ekonomi dan perdagangan internasional memiliki keterkaitan satu sama lain,perdagangan internasional merangsang pertumbuhan ekonomi jangka panjang. Semakin banyak aktivitas perdagangan disuatu negara maka semakin pesat pertumbuhan ekonominya, dengan demikian perdagangan merupakan komponen kunci pembangunan disuatu negara, kontribusinya sangat dirasakan dengan semakin meningkatnya pertumbuhan ekonomi di beberapa negara. Namun bagaimana dengan negara Indonesia, terdapat perlakuan yang berbeda untuk negara Indonesia, sebagai negara berkembang, Indonesia merupakan negara dengan nilai ekspor yang cukup stabil, terbukti sejak tahun 2017-2018, pertumbuhan ekspor naik $10 \%$, dengan nilai impor yang stabil (Statistik Indonesia, 2019). Asumsi ekspor yang positif dan impor yang stabil di Indonesia menunjukkan tingkat keterbukaan perdagangan di Indonesia memiliki dampak terhadap perekonomian khususnya pertumbuhan ekonomi dari sisi GDP.

Perdagangan internasional diyakini sebagai salah satu katalisator produktivitas dan pertumbuhan ekonomi dan kontribusinya sangat diperhitungkan dalam kegiatan ekonomi. Negara yang aktif secara internasional cenderung lebih produktif daripada negara yang hanya memproduksi untuk pasar lokal. Selain itu, perdagangan internasional mempromosikan alokasi sumber daya yang efisien dan dapat mengarah ke tingkat yang lebih tinggi. Pertumbuhan ekonomi juga dikaitkan dengannya penyebaran teknologi dan penyebaran pengetahuan (Vehapi, Sadiku and Petkovski, 2015).

Terdapat beberapa perbedaan persepsi antara hubungan keterbukaan perdagangan dengan pertumbuhan ekonomi, terdapat hubungan positif antara keterbukaan perdagangan dengan pertumbuhan ekonomi (Frankel dan Romer, 1999). Sachs dan Warner, 1995 berpendapat negara-negara terbuka menunjukkan tingkat pertumbuhan yang lebih tinggi daripada negara-negara proteksionis, lebih lanjut Dollar dan Kraay (2004) menjelaskan keterbukaan perdagangan yang besar akan meningkatkan pertumbuhan ekonomi,

Chen dan Gupta (2006) serta Chang et al. (2009) menyebutkan terdapat beberapa faktor pendukung pertumbuhan ekonomi dan kinerja perdagangan global, yaitu adanya penanaman modal asing (PMA), kesiapan sektor finansial (sistem keuangan), stabilitas perekonomian dan harga, infrastruktur publik, kualitas modal manusia, kemajuan teknologi, dan ketenagakerjaan.

Selain itu inflasi juga diyakini sebagai penyokong pertumbuhan ekonomi. Bittencourt (2012) menyatakan bahwa salah satu factor yang sangat berpengaruhi terhadap pertumbuhan ekonomi adalah inflasi. Selain itu Valdovinos (2003) menyatakan bahwa dalam jangka panjang meskipun tidak ada hubungan yang jelas antara inflasi dan pertumbuhan ekonomi namun setelah menggunakan metode Baxter dan King Filter ditemukan hubungan yang jelas dalam jangka panjang antara inflasi dan pertumbuhan ekonomi.

$$
\text { Selain inflasi faktor penentu }
$$
pertumbuhan ekonomi juga faktor 
ketersediaan tenaga kerja karena tenaga kerja dalam satu perekomian merupakan salah satu faktor yang mendorong pertumbuhan ekonomi. Investasi dalam pembinaan sumber daya manusia dapat menigkatkan modal manusia, sehingga pada akhirnya akan membawa dampak positif yang sama terhadap angka produksi, bahkan lebih besar mengingat terus bertambahnya jumlah manusia ( Todaro, Smith : 2002).

Hipotesis dalam penelitian ini sesuai dengan yang dikembangan dalam studi teoritis maupun empiris sebagai berikut:

1. Keterbukaan perdagangan memilki dampak positif terhadap pertumbuhan ekonomi di Indonesia.

2. Inflasi memiliki dampak positif terhadap pertumbuhan ekonomi di Indonesia.

3. Tenaga Kerja memiliki dampak positif terhadap pertumbuhan ekonomi di Indonesia.

Berdasarkan permasalahan diatas maka permasalahan penelitian ini adalah bagaimana dampak keterbukaan perdagangan,inflasi dan jumlah tenaga kerja terhadap petumbuhan ekonomi di Indonesia.

Tujuan penelitian ini untuk mengetahui dampak keterbukaan perdagangan, inflasi dan jumlah tenaga kerja terhadap petumbuhan ekonomi terhadap pertumbuhan ekonomi di Indonesia

\section{Kajian Pustaka}

\section{Pertumbuhan Ekonomi}

Pertumbuhan ekonomi diartikan sebagai kenaikan dari pendapatan nasional biasanya dikur dengan kenaikan PDB, Arsyad (2010) menyebutkan Pertumbuhan ekonomi diartikan sebagai kenaikan PDB atau PNB tanpa memandang apakah kenaikan itu lebih besar atau lebih kecil dari tingkat pertumbuhan penduduk, dan apakah terjadi perubahan struktur ekonomi atau perbaikan sistem kelembagaan atau tidak.

Fungsi produksi cobb-douglass merupakan wujud dari teori pertumbuhan ekonomi neo-kalsik yaitu melihat output merupakan fungsi dari tenaga kerja dan modal, dan kemajuan teknologi merupakan variabel eksogennya.

Fungsi cobb doglass dapat disajikan sebagai berikut :

$$
\mathrm{Qt}=\mathrm{Tt} \mathrm{Kta} \mathrm{Ltb}
$$

keterangan:

$\mathrm{Q}$ adalah tingkat produksi;

$\mathrm{T}$ adalah tingkat teknologi;

$\mathrm{K}$ adalah jumlah stok barang modal;

$\mathrm{L}$ adalah jumlah tenaga kerja;

a adalah pertambahan output yang diciptakan oleh penambahan satu unit modal;

b adalah pertambahan output yang diciptakan oleh penambahan satu unit tenaga kerja;

serta t menunjukkan tahun tertentu.

Asumsi CRTS menyatakan bahwa $a+b=1$, artinya nilai a dan $b$ merupakan batas produksi dari masing-masing produksi tersebut (Arsyad, 2010).

Pertumbuhan ekonomi menurut Sukirno (2010) adlah perkembangan kegiatan perekonomian yang menyebabkan barang jasa dang di produksikan masyarakat bertambah. Sedangkan menurut Adisasmita (2013), pertumbuhan ekonomi dapat diartikan kenaikan dalam tingkat pendapatan di negara maju, seperti perkembangan ekonomi, kesejahteraan ekonomi, kemajuan ekonomi dan perubahan jangka panjang. 
Jadi Pertumbuhan ekonomi adalah proses kenaikan produk domestic bruto dari tahun ke tahun. Untuk mengukur Pertumbuhan ekonomi biasanya digunakan nilai PDB suatu negara.

\section{Inflasi}

Menurut Sukirno (2006) ada 2 jenis inflasi jika dilihat dari sumbernya, yang pertama adalah kenaikan harga secaara umum yang disebabkan oleh permintaan masyarakat akan barang dan jasa terlalu kuat (Demand Push Inflation), yang kedua adalah inflasi yang diakibatkan oleh tingginya biaya produksi (cost push inflation).

Inflasi merupakan masalah utama di banyak Negara berkembang. Inflasi menyebabkan kenaikan tingkat harga. 6 Inflasi tinggi menyebabkan daya beli mata uang suatu Negara semakin turun. Menurut Sukirno (2001:15) adalah suatu proses kenaikan harga-harga yang berlaku dalam suatu perekonomian. Sehingga dapat disimpulkan bahwa inflasi disini merupakan suatu proses kenaikan harga dimana kenaikan tersebut berpengaruh atau berlaku di dalam suatu perekonomian.

$$
\text { Jenis-jenis Inflasi Menurut }
$$

Samuelson dan Nordhaus (2005:312) menjelaskan bahwa inflasi dilihat dari tingkat derajat atau kejadian parah antara lain:

a) Inflasi moderat (Moderat Inflation), yaitu ditandai naiknya harga secara lambat dan dapat diramalkan. Kita dapat menyebutnya sebagai laju inflasi satu pertahun, karena apabila barang-barang relatif stabil masyarakat percaya pada uang.

b) Inflasi Ganas (Galloping Inflation), yaitu inflasi dalam dua digit atau tiga digit seperti
20, 100, atau 200 persen pertahun. Inflasi ganas timbul, maka timbul juga gangguan yang serius terhadap perekonomian.

c) Hiperinflasi, yaitu ketika ekonomi Nampak selamat dari inflasi yang melambung ketegangan ketiga dan mematikan mengambil alih ketika hiperinflasi menyerang.

\section{Tenaga Kerja}

Tenaga kerja adalah setiap orang laki - laki maupun wanita yang sedang dalam atau akan melakukan pekerjaan, baik luar maupun dalam hubungan kerja guna menghasilkan barang atau jasa untuk memenuhi kebutuhan masyarakat, dengan kata lain orang dalam usia kerja dianggap mampu bekerja. Lewis mengemukakan teorinya mengenai ketenagakerjaan, yaitu; kelebihan pekerja merupakan kesempatan dan bukan masalah. Kelebihan pekerja satu sektor akan memberikan andil terhadap pertumbuhan output dan penyediaan pekerja di sektor lain. Selanjutnya Lewis mengemukakan bahwa ada dua sektor di dalam perekonomian negara sedang berkembang, yaitu sektor modern dan sektor tradisional. Sektor tradisional tidak hanya berupa sektor pertanian di pedesaan, melainkan juga termasuk sektor informal di perkotaan (pedagang kaki lima, pengecer, pedagang angkringan). Sektor informal mampu menyerap kelebihan tenaga kerja yang ada selama berlangsungnya proses industrialisasi, sehingga disebut katub pengaman ketenagakerjaan. Dengan terserapnya kelebihan tenaga kerja disektor industri (sektor modern) oleh sektor informal, maka pada suatu saat tingkat upah di pedesaan akan meningkat. Peningkatan 
upah ini akan mengurangi perbedaan tingkat pendapatan antara pedesaan dan perkotaan, sehingga kelebihan penawaran pekerja tidak menimbulkan masalah pada pertumbuhan ekonomi.

Tenaga kerja merupakan faktor produksi yang sangat penting yang secara aktif mengolah sumber lain. Tenaga kerja adalah penduduk yang sedang atau sudah bekerja, sedang mencari pekerjaan dan yang melakukan kegiatan-kegiatan lain, seperti bersekolah dan mengurus rumah tangga. Batas umur tenaga kerja minimum 10 tahun tanpa batas umur maksimum (Simanjuntak, 1998).

\section{Hubungan Pertumbuhan Ekonomi dengan Keterbukaan Perdagangan}

Hubungan teori pertumbuhan ekonomi dengan perdagangan dapat dijelaskan menggunakan teori keunggulan absolut adam smith tahun 1776 dan teori keunggulan komparatif david ricardo tahun 1817 (Salvatore, 1997). Teori keunggulan absolutmenyebutkan jika suatu negara memproduksi komoditas lebih efisien dibandingkan negara lain dan kurang efisien dalam memproduksi komoditas lain dibandingkan negara lain maka kedua negara tersebut dapat melakukan spesialisai produk dengan menukarkan komoditas yang memiliki keunggulan absolut dengan komoditas yang memiliki kerugian absolut.

Sedangkan teori keunggulan komparatif menyebutkan walaupun suatu negara kurang efisien dalam memproduksi suatu komoditas dibandingkan dengan negara lain artinya negara tersebut tidak memiliki keunggulan absolut tapi kedua negara tersebut masih dapat melakukan perdagangan yang menguntungkan, teori yang dikemukakan david ricardo ini juga menyebutkan perdagangan dapat terjadi antar negara apabila terdapat keunggulan komparatif, keunggulan komparratif akan tercapai jika suatu negara mampu memproduksi barang dan jasa yang lebih banyak dan murah dibandingkan negara lainnya.

\section{Hubungan Pertumbuhan Ekonomi dengan Inflasi}

Aydın, Esen and Bayrak, 2016 menyatakan bagaimana inflasi yang dialami mempengaruhi tingkat pertumbuhan.Temuan yang diperoleh memberikan bukti baru tentang adanya hubungan non linier antar inflasi dan pertumbuhan ekonomi di ekonomi transisi dalam jangka panjang. Selain itu, temuan ini menunjukkan bahwa saat terjadi inflasi di atas nilai kritis tertentu di negara-negara tersebut, inflasi akan berpengaruh negatif terhadap pertumbuhan ekonomi.

Attari, Javed, 2013 menyatakan bahwa ada hubungan jangka panjang antara tingkat inflasi, pertumbuhan ekonomi dan pengeluaran pemerintah artinya bahwa ada kausalitas searah antara tingkat inflasi dengan pertumbuhan ekonomi, dan pertumbuhan ekonomi dengan pemerintahan pengeluaran.

Dari sebuah studi yang dilakukan oleh Mohseni, Jouzaryan. 2016 terdapat pengaruh negative antara inflasi dan pengangguran terhadap pertumbuhan ekonomi. Setiap Negara memiliki kondisi geografis yang berbeda sehingga target inflasi yang optimal mungkin khusus untuk negara tertentu. Pembuat kebijakan 
khususnya di Negara Asiaperlu mempertimbangkan tarif maksimal inflasi sampai pada ambang batas tertentu sebagai sasaran inflasi untuk menjaga stabilitas ekonomi, dengan demikian pertumbuhan ekonomi dapat ditingkatkan serta dapat mengurangi hambatan perdagangan dan memotivasi investasi.

\section{Hubungan Pertumbuhan Ekonomi dengan Tenaga Kerja}

Pertumbuhan penduduk yang meningkat dari waktu ke waktu akan mempengaruhi jumlah tenaga kerja yang ada. Namun jumlah tenaga kerja yang besar harus diikuti dengan kualitas tenaga kerja. Sehingga, keadaan tersebut mampu meningkatkan kapasitas produksi dan mampu memacu pertumbuhan ekonomi.

Menurut Todaro (2000), pertumbuhan penduduk dan pertumbuhan angkatan kerja secara tradisional dianggap sebagai salah satu faktor positif yang memacu pertumbuhan ekonomi. Jumlah tenaga kerja yang lebih besar berarti akan menambah tingkat produksi, sedangkan pertumbuhan penduduk yang lebih besar berarti ukuran pasar domestiknya lebih besar. Meski demikian hal tersebut masih dipertanyakan apakah benar laju 31 pertumbuhan penduduk yang cepat benar-benar akan memberikan dampak positif atau negatif dari pembangunan ekonominya. Dalam pertumbuhan ekonomi jumlah tenaga kerja yang bekerja merupakan salah satu faktor yang akan memengaruhi pertumbuhan ekonomi di suatu wilayah. Selain faktor produksi, jumlah tenaga kerja yang bekerja juga akan meningkat dari tahun ke tahun sehingga apabila dimanfaatkan dengan maksimal maka akan meningkatkan pertumbuhan ekonomi.

Menurut Samuelson dan Nordhaus (2004) input tenaga kerja terdiri dari kuantitas tenaga kerja dan ketrampilan angkatan kerja. Tenaga kerja yang melimpah harus diikuti dengan kualitas yang dimilikinya. Kualitas input tenaga kerja meliputi ketrampilan, pengetahuan, dan disiplin angkatan kerja. Kemajuan teknologi yang semakin cepat akan efektif digunakan oleh tenaga kerja yang terampil dan terlatih. Perbaikanperbaikan dalam bidang pendidikan, kesehatan, serta disiplin tenaga kerja akan menambah produktivitas tenaga kerja. Sehingga tenaga kerja terdidik dan memiliki disiplin yang tinggi penting dimiki suatu negara atau daerah untuk meningkatkan pertumbuahn ekonominya

\section{Penelitian Terdahulu}

Pradhan, 2017 et al menyebutkan ada hubungan jangka panjang antara keterbukaan perdagangan, kedalaman sektor perbankan, dan pertumbuhan ekonomi, tetapi sifat hubungan kausal itu kompleks, lebih lanjut pradhan,2017 arah kebijakan untuk mendorong pertumbuhan ekonomi dalam jangka panjang harus berupaya mengembangkan sektor perbankan mereka dan mempromosikan kebijakan perdagangan bebas.

Vehapi, Sadiku, and Petkovski, 2015 menyatakan keterbukaan perdagangan mendorong pertumbuhan negara-negara dengan PDB per kapita yang lebih tinggi (atau negara-negara kaya), keterbukaan perdagangan akan menguntungkan negaranegara dengan pembentukan modal tetap 
bruto lebih tinggi dan negara yang memiliki FDI lebih tinggi.

Penelitian Chen dan Gupta (2006) serta Chang et al. (2009) diketahui bahwa dampak positif keterbukaan perdagangan terhadap pertumbuhan ekonomi ditentukan oleh kondisi dan perbaikan-perbaikan yang dilakukan oleh setiap negara pada faktorfaktor lain sebagai pendukungnya.

Bojanic, 2012 menunjukkan bahwa terdapat keseimbangan jangka panjang hubungan antara pertumbuhan ekonomi, perkembangan keuangan dan keterbukaan perdagangan. Selanjutnya, hasil kausalitas Granger ditemukan terdapat hubungan indikator keuangan,indikator pembangunan dan keterbukaan perdagangan terhadap pertumbuhan ekonomi.

\section{Kyophilavong,et}

al

menyatakan keterbukaan perdagangan mendorongpertumbuhan ekonomi dan umpan baliknya akan mendorong konsumsi energi.

Shahbaz, et al (2016) berpendapat keterbukaan perdagangan mengurangi emisi karbon di sebagian besar negara, keterbukaan perdagangan menyebabkan emisi $\mathrm{CO} 2$ untuk kalangan negara-negara berpenghasilan tinggi dan rendah dalam jangka panjang.

Bittencourt (2012) menyatakan bahwa salah satu factor yang sangat berpengaruhi terhadap pertumbuhan ekonomi adalah inflasi. Selain itu Valdovinos (2003) menyatakan bahwa dalam jangka panjang meskipun tidak ada hubungan yang jelas antara inflasi dan pertumbuhan ekonomi namun setelah menggunakan metode Baxter dan King Filter ditemukan hubungan yang jelas dalam jangka panjang antara inflasi dan pertumbuhan ekonomi.

\section{Metode Penelitian}

Penelitian ini merupakan penelitian kuantitatif, penelitian kuantitatif merupakan penelitian dengan melihat data-data angka kemudian diuji statistik.

Tujuan penelitian ini bersifat eksplanatori (explanatory research) dimana penelitian eksplanatori merupakan jenis penelitian yang menjelaskan hubungan kausal antara satu variabel dengan variabel lainnya melalui pengujian hipotesis.

Objek dalam penelitian ini adalah Indonesia dengan melihat dampak keterbukaan perdagangan, inflasi dan jumlah tenaga kerja terhadap pertumbuhan ekonomi.

Teknik pengumpulan data menggunakan studi dokumentasi dengan mengumpulkan data sekunder, mencatat, dan mengolah data yang berkaitan dengan penelitian ini. Menurut Azwar (2001 :91) Data sekunder biasanya berwujud data dokumentasi atau data laporan yang telah tersedia.

Data yang di gunakan meliputi Trade Openness, inflasi, dan jumlah tenaga kerja serta Pertumbuhan Ekonomi (GDP). Sedangkan jenis data yang digunakan adalah data time series tahun 1986-2018. Sumber data di peroleh dari World Bank.

Spesifikasi model penelitian ini dituliskan pada persamaan 1, sebagai berikut:

$g d p=f($ tradeopenness, Inf , Empy) (1)

Dimana model tersebut kemudian ditransformasikan kedalam model ekonometrika menjadi sebagai berikut: 
$g d p_{t}=\beta_{0}+\beta_{1}$ Trade $_{t}+\beta_{2}$ inf $_{t}+$

$\beta_{3}$ emply $_{t}+\varepsilon_{t}$

Dimana:

$g d p_{t} \quad=$ Pertumbuhan Ekonomi

(\%) pada periode $\mathrm{t}$

Trade $_{t}=$ Keterbukaaan

Perdagangan (\%) pada periode $\mathrm{t}$

inft $\quad=$ Inflasi $(\%)$ pada periode $\mathrm{t}$

emply $_{t} \quad=$ Total Jumlah Tenaga

Kerja (\% Total Penduduk) pada periode $\mathrm{t}$

$\beta \quad=$ Koefisien

$\varepsilon=$ error term

Persamaan 2 kemudian

ditransformasikan kedalam model

Generalized Method of Moments menjadi sebagai berikut:

$g d p_{t}=\beta_{0}+\beta_{1}$ Trade $_{t}+\beta_{2}$ inf $_{t}+$

$\beta_{3}$ emply $y_{t}+g d p_{t-1}+\varepsilon_{t}$

Kemudiaan moment dari persamaan tersebut adalah:

$E(e i)=0$

$E\left(g d p_{t}-\beta_{0}-\beta_{1} g d p_{t}-\beta_{2}\right.$ Trade $_{t}-$

$-\beta_{3}$ inf $_{t}-\beta_{4}$ emply $\left._{t}-\varepsilon_{t}\right)=0$

Teknik analisis data menggunakan metode GMM yang dikembangkan oleh Holtz-Eakin dkk (1998) dan Arellano dan Bond (1991). Prosedur yang digunakan memberikan beberapa keuntungan terhadap perkembangan model panel yang melibatkan variabel terikat. Pertama, potensi yang dapat menyebabkan bias pada estimator dihilangkan dengan jalan meniadakan $\mu$ (penganggu). Kedua, penggunaan variabel instrumen dapat menghasilkan estimator yang konsisten walaupun terdapat variabel endogen dalam model yang diestimasi. Ketiga, penggunaan variabel instrumen memungkinkan keberadaan estimator yang konsisten walaupun terdapat variabel error (Oliveira et.al, 2005)

Estimator GMM menggunakan persamaan first difference.Transformasi ini akan menghilangkan $\mu$ serta memungkinkan variabel variabel endogen pada periode kedua dan sebelumnya untuk menjadi variabel instrumen yang tepat asalkan tidak terdapat korelasi serial pada random error. Hal itu dapat diuji dengan menggunakan uji untuk korelasi serial untuk residual dalam bentuk first difference. Model autoregressive distributed lag dapat terjadi bias pada estimator first difference sebagai akibat lemahnya variabel instrument karena tidak terdapat hubungan yang erat antara variabel dan variabel instrumennya (Blundell and Bond, 1998). Cara yang sederhana untuk mendeteksi keberadaan lemahnya variabel instrumen adalah melakukan uji validitas instrumen menggunakan Sargan SpecificationTest. Jika variabel instrumen yang digunakan lemah, maka parameter yang dihasilkan oleh GMM-diff akan tetap mengalami bias.

\section{Hasil dan Pembahasan Hasil Analisis}

Hasil pengujian menggunakan metode analisis Generalized Method of Moments akan dijelaskan pada Tabel 2. Hasil analisis menggunakan metode GMM menujukkan bahwa seluruh variable berpengaruh signifikan terhadap dinamika pertumbuhan ekonomi di Indonesia. Hasil ini dibuktikan dengan nilai probabilitas t-statistik yang menunjukkan nilai lebih kecil 
dibandingankan dengan nilai t-tabel. Kemudian nilai tersebut juga memiliki probabilitas kurang dari nilai $\alpha$. Hasil GMM untuk variabel perdagangan, FDI, inflasi, dan jumlah tenaga kerja menunjukkan memiliki pengaruh signifikan terhadap pertumbuhan ekonomi, dimana hasil ini ditunjukkan dengan nilai probabilitas kurang dari nilai $\alpha$. Kemudian hasil estimasi menggunakan GMM menunjukkan nilai $\mathrm{j}$ statistik sebesar 0,03, dimana nilai tersebut memiliki besaran kurang dari nilai $\alpha=5 \%$. Hasil tersebut membuktikan bahwa instrument yang digunakan dalam model dan model yang digunakan bersifat valid. Kemudian diketahui bahwa nilai adj Rsquared adalah sebesar 0.81 yang mana hasil ini memberikan gambaran bahwa seluruh variabel independent mampu menjelaskan variabel dependen sebesar $81 \%$.

Tabel 1. Hasil analisis Generalized Method of Moments

\begin{tabular}{|c|c|c|c|c|}
\hline \multirow[b]{2}{*}{ el } & \multirow[t]{2}{*}{ Variab } & \multicolumn{2}{|l|}{ Koefisie } & \multirow[t]{2}{*}{ Probablit } \\
\hline & & n T-Statistik & as & \\
\hline \multirow{6}{*}{$\mathrm{n}$} & Trade & $\begin{array}{c}- \\
1.836350\end{array}$ & & $0.0753 *$ \\
\hline & Inflasio & 1.55283 & & $01300 *$ \\
\hline & & 8 & & \\
\hline & Employ & 10.2277 & & $0.0000 * * *$ \\
\hline & \multicolumn{2}{|c|}{ Prob J-Statistik } & & 0.035058 \\
\hline & \multicolumn{2}{|c|}{ Adjusted R-squared } & & 0.817471 \\
\hline
\end{tabular}

** Signifikan 5\%

$* * *$ Signifikan $1 \%$

Sumber : Hasil Olah Eviews, 2020

Selanjutnya Uji Asumsi klasik dalam penilitian ini bertujuan untuk menghasilkan estimator yang linier yang tidak bias dengan varian yang minimum (Best Linier Unbiased Estimator=BLUE) agar tidak terjadi regresi yang lancung. Adapun tahapan-tahapan yang harus dilakukan adalah dengan melakukan beberapa uji yaitu uji autokorelasi, normalitas, dan heterokesdatisitas. Berikut akan ditampilkan hasil diagnosis uji asumsi klasik di Indonesia.

Tabel 5.3. Hasil Uji Asumsi Klasik

\begin{tabular}{lrrrr}
\hline $\begin{array}{c}\text { Uji } \\
\text { Diagnosis }\end{array}$ & est & T & $\begin{array}{c}\text { Output } \\
\text { Hitung }\end{array}$ & $\begin{array}{c}\text { Proba } \\
\text { blitas }\end{array}$ \\
\hline $\begin{array}{c}\text { Autoko } \\
\text { relasi }\end{array}$ & $\begin{array}{r}\text { L } \\
\text { M Test } \\
\text { Normal }\end{array}$ & 3.940642 & 0.0299 \\
itas & $\begin{array}{r}\text { C } \\
\text { holesky } \\
\text { Hetero }\end{array}$ & 5.718685 & 0,0579 \\
kedastisitas & hite & & \\
& Test & 7.204728 & 0.0299 \\
\hline
\end{tabular}

Sumber : Hasil Olah Eviews, 2020

Hasil uji asumsi klasik yang dijelaksan pada Tabel 5.3 menunjukkan bahwa model yang digunakan dalam penelitian ini bersifat BLUE. Hal ini didasarkan atas beberapa terpenuhinya syarat uji diagnosis asumsi klasik, dimana dalam penelitian ini tidak terdapat autokorelasi antar variabelnya, kemudian data terdistribusi secara normal dan tidak terdapat heterokedastisitas.

\section{Pembahasan}

\section{Diskusi Hasil Analisis Trade Openness dan Pertumbuhan Ekonomi di Indonesia}

Hasil pegujian menggunakan metode GMM diketahui bahwa pada variabel perdagangan berpengaruh signifikan 
terhadap pertumbuhan ekonomi di Indonesia. Hasil ini semakin menegaskan bahwa peningkatan terhadap perdagangan akan berdampak terhadap pertumbuhan ekonomi di Indonesia. Temuan empiris sesuai dengan penelitian yang dilakukan oleh Kong, Peng, Ni, Jiang, \& Wang, 2020; Pradhan, Arvin, Hall, \& Norman, 2017; Riekhof, Regnier, \& Quaas, 2019. Beberapa temuan empiris yang tersebut memberikan penegasan bagaimana dampak keterbukaan perdagangan terhadap pertumbuhan ekonomi di suatu negara. Adapun kondisi tersebut dipengaruhi oleh beberapa kondisi ekonomi, social, politik yang memengaruhi tingkat keterbukaan suatu negara, sehingga hal tersebut berpengaruh terhadap kinerja perdagangan internasionalnya.

Perkembangan kondisi globalisasi pada saat ini berdampak pada peningkatan keterbukaan perekonomian suatu negara yang menumbuhkan suatu integrasi antar wilayah negara, kondisi ini semakin menghilangkan batasan-batasan antar negara. Keterbukaaan ini berdampak pada peningkatan arus ekonomi yang cepat antar negara dalam suatu kawasan seperti perdagangan, investasi, dan dalam jangka waktu tertentu dapat meningkatkan pertumbuhan ekonomi. Dalam perkembangannya tingkat keterbukaan dan integrasi ekonomi yang menghiangkan Batasan-batasan disuatu kawasan negara juga memberikan dampak ataupun risiko negatif adanya spillover dari negara mitra atau negara lain yang berdampak pada kinerja perekonomian di suatu negara.

Sektor perdagangan di Indonesia menjadi salah satu sektor utama kontributor pertumbuhan ekonomi pada saat ini, dimana kontributor utama pertumbuhan ekonomi di Indonesia disumbakan oleh sector industri, pertanian, dan perdagangan (Badan Pusat Statistik, 2019). Tingkat keterbukaan perdagangan yang massif ditengah kondisi yang semakin terintegrasi antar negara diharapkan mampu menunjang adanya pertumbuhan ekonomi Indonesia. Namun adanya keterbukaan dan integrasi ekonomi tersebut juga dapat menimbulkan risiko negatif yang dapat terjadi apabila ada gejolak perekonomian. Kebijakan integrasi dan keterbukaan perdagangan serta pemanfaatan sector-sektor potensial yang ada diharapkan mampu memberikan kontribusi yang lebih terhadap pertumbuhan ekonomi di Indonesia.

\section{Diskusi Hasil Analisis Inflasi dan Pertumbuhan Ekonomi di Indonesia}

Hasil analisis inflasi menggunakan metode GMM diketahui bahwa variabel Inflasi berpengaruh terhadap pertumbuhan ekonomi di Indonesia. Hal ini ditandai dengan temuan empiris seperti yang dikemukakan Aydın, Esen and Bayrak, 2016 menyatakan adanya tingkat inflasi yang optimal atau ada tidaknya ambang batas dalam transisiekonomi di mana negara menjalankan tugas aktif dalam proses pembentukan ekonomi pasar dan memiliki pertumbuhan ekonomi yang cepat mempengaruhi pembentukan harga di pasar dengan keputusan yang mereka buat atau tidak. Dia juga menyatakan bagaimana inflasi yang dialami mempengaruhi tingkat pertumbuhan.Temuan yang diperoleh memberikan bukti baru tentang adanya hubungan non linier antar inflasi dan pertumbuhan ekonomi di ekonomi transisi 
dalam jangka panjang. Selain itu, temuan ini menunjukkan bahwa saat terjadi inflasi di atas nilai kritis tertentu di negara-negara tersebut, inflasi akan berpengaruh negatif terhadap pertumbuhan ekonomi.,nilai kritis yang diprediksi ditemukan menjadi 7,97\% untuk ekonomi transisi yang diperiksa.

Attari, Javed, 2013 menyatakan bahwa ada hubungan jangka panjang antara tingkat inflasi, pertumbuhan ekonomi dan pengeluaran pemerintah, artinya pengeluaran pemerintah menghasilkan eksternalitas dan keterkaitan yang positif. Dalam jangka pendek tariff inflasi tidak mempengaruhi pertumbuhan ekonomi tetapi pengeluaran pemerintah mempengaruhi pertumbuhan ekonomi. Hasil uji kausalitas menunjukkan bahwa ada kausalitas searah antara tingkat inflasi dengan pertumbuhan ekonomi, dan pertumbuhan ekonomi dengan pemerintahan pengeluaran.

Dari sebuah studi yang dilakukan oleh Mohseni, Jouzaryan. 2016 terdapat pengaruh negative antara inflasi dan pengangguran terhadap pertumbuhan ekonomi. Setiap Negara memiliki kondisi geografis yang berbeda sehingga target inflasi yang optimal mungkin khusus untuk negara tertentu. Pembuat kebijakan khususnya di Negara Asiaperlu mempertimbangkan tarif maksimal inflasi sampai pada ambang batas tertentu sebagai sasaran inflasi untuk menjaga stabilitas ekonomi, dengan demikian pertumbuhan ekonomi dapat ditingkatkan serta dapat mengurangi hambatan perdagangan dan memotivasi investasi.

\section{Diskusi Hasil Analisis Jumlah Tenaga Kerja dan Pertumbuhan Ekonomi di Indonesia}

Hasil GMM untuk variabel jumlah tenaga kerja menunjukkan pengaruh signifikan terhadap pertumbuhan ekonomi hal ini senada seperti yang dikemukakan oleh Ioana, 2014. Meningkatnya kuantitas dan kualitas dari jumlah tenaga kerja akan mengakibatkan peningkatan pada pertumbuhan ekonomi. Dengan beberapa program seperti membuka lapangan kerja baru khususnya dibidang pertanian justru akan memunculkan keunggulan komparatif maupun kompetitif pada setiap Negara basis sektor pertanian, hal tersebut diyakini akan semakin memperluas pertumbuhan ekonomi pada semua lini tidak hanya sektor industry tapi ke sektor pertanian dan jasa.

Tenaga kerja merupakan suatu tonggak sumberdaya manusia untuk mewujudkan pertumbuhan ekonomi karena tenaga kerja yang produktif akan memberikan sumbahsih terhadap keberhasilan pertumbuhan ekonomi, hal ini tentunya harus didukung oleh keberhasilan dalam bidang pendidikan, guna mewujudkan sumberdaya yang handal. Masalah ketidakseimbangan permintaan dan penawaran tenaga kerja menjadi salah satu hambatan pekerja hal ini disebabkan oleh beberapa factor yaitu pendidikan, upah, kondisi social ekonomi suatu Negara,dll. Sebagai contoh factor pendidikan di Indonesia, para pekerja dituntut melalui wajib belajar 9 tahun, program ini bertujuan guna memantapkan pekerja sehingga mempercepat proses pertumbuhan ekonomi. 


\section{Kesimpulan}

Dapat disimpulkan Penelitian ini menganalsis hubungan keterbukaan perdagangan (trade openness), inflasi dan jumlah tenaga kerja dengan tingkat pertumbuhan ekonomi di Indonesia. Metode estimasi Generalized Method of Moment (GMM) digunakan untuk menganalisis hubungan antar variabel. Hasil estimasi menggunakan GMM diketahui bahwa variabel keterbukaan perdagangan berpengaruh signifikan terhadap pertumbuhan ekonomi di Indonesia, selain itu pada variabel control yaitu variabel makroekonomi juga berpengaruh signifikan terhadap pertumbuhan ekonomi di Indonesia. Hasil ini sekaligus memberikan gambaran tentang pengaruh keterbukaan perdangan yang memiliki kontribusi positif terhadap kinerja perekonomian Indonesia khususnya terhadap pertumbuhan ekonomi. Adanya keterbukaan perdagangan juga memberikan risiko terhadap kinerja perekonomian domestic sebagai akibat dari gejolak yang terjadi pada perekonomian luar negeri. Kebijakan ekonomi yang tepat dalam mengontrol keterbukaan perdagangan diharapkan dapat mengurangi risiko tersebut dan memberikan pengaruh yang positif terhadap perekonomian Indonesia.

\section{Daftar Pustaka}

Arellano, M.\& Bond, S. (1991), "Some Tests of Specification for Panel Data: Monte Carlo Evidence and an Application to Emplyment Equations" Review of Economic studies, 58(2): 277-297

Arsyad, L. 2010. Ekonomi Pembangunan. Edisi 5. UPP STIM YKPN, Yogyakarta.
Attaria. Muhammad Irfan Javaid, Javed. A.Y .(2013). Inflation, Economic Growth and Government Expenditure of Pakistan: 1980-2010. International Conference On Applied Economics (ICOAE). Procedia Economics and Finance 5 ( 2013 ) 58 - 67.

Azwar, Saifudin. 2001. Metode Penelitian. Pustaka Pelajar Offset : Yogyakarta

Bittencourt, M. (2012). Inflation and economic growth in Latin America: Some panel timeseries evidence. Economic Modelling, 333-340.

Blundell, R., \& Bond, S. (1998). Initial Conditions and Moment Restrictions in Dynamic Panel Data Models. Journal of Econometrics, 87(1),115-143.

Bojanic, A.N., 2012. The impact of financial development and trade on the economic growth of Bolivia. J. Appl. Econ. 15 (1), 51-70.

Chang, R., L. Kaltani, dan N.V. Loayza. 2009. Openness Can be Good for Growth: The Role of Policy Complementarities. Journal of Development Economics, 90: 3349.Arsyad (2010).

Chen, P. dan R. Gupta. 2006. An Investigation of Openness and Economic Growth Using Panel Estimation. Working Paper: 2006-22, November 2006.

Dollar, D. dan A. Kraay. 2001. Trade, Growth, and Poverty. Development Research Group, The World Bank, June 2001. 
Esen.O, Bayrak. M. (2016). Inflation and Economic Growth: A Dynamic Panel Threshold Analysis for Turkish Republics in Transition Process. Celil Aydin , Procedia - Social and Behavioral Sciences 229 ( 2016 ) $196-$ 205.

Frankel, J.A. dan D. Romer. 1999. Does Trade Cause Growth?. American Economic Review, 89: 379-399. Sachs dan Warner, 1995.

Holtz-Eakin, D., Newey, W., Rosen, H.S., 1988. Estimating vector auto regressions with panel data. Econometrica 56 (6), 1371-1395.

Ioana.D (2014).Employment - cause and effect of the economic growth. 1st International Conference 'Economic Scientific Research - Theoretical, Empirical and Practical Approaches', ESPERA 2013. Procedia Economics and Finance 8 ( 2014 ) 268 - 274.

Jeffrey D. Sachs, Andrew M. Warner. 1995. Economic Fluctuations and Growth, International Finance and Macroeconomics, Environment and Energy Economics. NBER Working Paper No. 5398 Issued in December 1995.

Kong, Q., Peng, D., Ni, Y., Jiang, X., \& Wang, Z. (2020). Trade openness and Economic Growth Quality of China: Empirical Analysis Using Ardl Model. Finance Research Letters, 101488. https://doi.org/10.1016/j.frl.2020.10148 8

Kyophilavong, Phouphet., Shahbaz, Muhammad., Anwar, Sabeen., Masood,
Sameen. 2015. The energy-growth nexus in Thailand: Does trade openness boost up energy consumption?. Renewable and Sustainable Energy Reviews 46 (2015)265-274.

Mohseni.M, Jouzaryan.F.(2016). Examining the Effects of Inflation and Unemployment on Economic Growth in Iran (1996-2012) 1st International Conference on Applied Economics and Business, ICAEB 2015. Procedia Economics and Finance 36 ( 2016 ) 381 -389 .

Oliveira et.al, 2005. Statistical analysis of cointegration vectors. J. Econ. Dyn. Control 12 (2-3), 231-254.

Pradhan, R. P., Arvin, M. B., Hall, J. H., \& Norman, N. R. (2017). ASEAN economic growth, trade openness and banking-sector depth: The nexus. EconomiA, 18(3), 359-379. https://doi.org/10.1016/j.econ.2017.05. 002.

Riekhof, M. C., Regnier, E., \& Quaas, M. F. (2019). Economic growth, international trade, and the depletion or conservation of renewable natural resources. Journal of Environmental Economics and Management, 97, 116133.https://doi.org/10.1016/j.jeem.2018 .04 .008 .

Salvatore, D. 1997. Ekonomi Internasional. Edisi Kelima. Terjemahan. Penerbit Erlangga, Jakarta.

Samuelson, P.A. dan Nordhaus, W.D. (2004). Ilmu Makro Ekonomi. (Alih Bahasa Gretta, Theresa T, Bosco C, Anna E). Media Global Edukasi. Jakarta 
Simanjuntak, P.J. (1985). Pengantar

Ekonomi Sumber Daya Manusia.

Fakultas Ekonomi Universitas

Indonesia. Jakarta

Shahbaz, Muhammad., Nasreen, Samia., Ahmed, Khalid., Hammoudeh, Shawkat. 2016. Trade OpennessCarbon Emissions Nexus: The Importance of Turning Points of Trade Openness for Country Panels. Energy Economics.

Sukirno, S. (2012). Makroekonomi Teori Pengantar Edisi Ketiga. Rajawali Pers. Jakarta

Todaro M.P dan Stephen C.S. (2002). Pembangunan Ekonomi di Dunia Ketiga. Erlangga. Jakarta

Valdovinos, C. G. (2003). Inflation and economic growth in the long run. Economics Letters, 167-173

Vehapi, Merale Fetahi, Sadiku, Luljeta, Petkovski, Mihail.2015. Empirical Analysis of the Effects of Trade Openness on Economic Growth: An Evidence for South East European Countries. Procedia Economics and Finance 19 ( 2015 ) 17 - 26.

World Bank (2018), World Bank Report. Washington: World Bank 